This is an electronic reprint of the original article. This reprint may differ from the original in pagination and typographic detail.

Author(s): Niemi, Kreeta

Title: $\quad$ "I will send badass viruses." Peer threats and the interplay of pretend frames in a classroom dispute

Year: $\quad 2014$

Version:

Please cite the original version:

Niemi, K. (2014). "I will send badass viruses." Peer threats and the interplay of pretend frames in a classroom dispute. Journal of Pragmatics, 66(May), 106-121. https://doi.org/10.1016/j.pragma.2014.02.012

All material supplied via JYX is protected by copyright and other intellectual property rights, and duplication or sale of all or part of any of the repository collections is not permitted, except that material may be duplicated by you for your research use or educational purposes in electronic or print form. You must obtain permission for any other use. Electronic or print copies may not be offered, whether for sale or otherwise to anyone who is not an authorised user. 


\section{"I will send badass viruses." Peer threats and the interplay of pretend frames in a classroom dispute}

\section{Abstract}

This paper explores threats as they appear in children's everyday dispute interactions. The main purpose is to extend understandings of children's interactions and disputes in order to show how young boys construct threats in pretend frames within a classroom peer dispute by drawing upon the resources of the video game world and a verbally-constructed fight. The conceptual and methodological frameworks underpinning analysis are conversation analysis and Goffman's concept of frame. The analysis focuses on one episode that shows how the boys, in the absence of teacher, invoke, share and switch frames within the dispute. Using pretence, they posit threats and build attack strategies in video game and in mass fight frames, even though they are in a classroom and unable to complete the threats at that moment. Analysis points out that the pretend threats are different to other sorts of threats and escalate the dispute sequence. Threats in pretend frame, like in video game frame, are also opportunities to bring activities outside school to the classroom, and this study also looks at how video game playing is used as a resource while not playing. The implications for broader educational practices are to show how language and social interaction function in children's peer interactions by uncovering the multifaceted aspects of peer culture, friendship and children's agentive roles in maintaining and creating social and moral order in different realities.

Key words: children, classroom interaction, disputes, threats, frames, video games

\section{Introduction}

The interest to study children's own methods for making sense of everyday interaction including dispute situations has increased in recent years. These kinds of studies have positioned children as 
competent language users and agentic actors in their social and cultural worlds, and uncovered the topics and strategies children use in peer disputes (e.g. Bateman 2010 \&2011; Butler 2008; BjörkWillen 2012; Church 2009; Cobb-Moore, Danby \& Farrell 2008; Danby \& Theobald 2012: Goodwin \& Goodwin 1987; Goodwin 1990, 2002 \& 2007; Sheldon 1996). Close examination of disputes have enabled interaction to be seen not just as children disputing, but as interactive work accomplishing social activities through various resources and emphasized the opportunities embedded within dispute situations in relation to contributing to children's social and linguistic competence, as well as moral reasoning and agency (e.g. Butler 2008; Church \& Mashford-Scott 2011; Goodwin 2007; Sheldon 1996). Most often, disputes among children have been studied in early childhood classrooms and nursery schools or in playground situations (see Bateman 2010; Butler 2008; Church 2009; Danby \& Theobald 2012).

This article builds on and contributes to the work of previous studies on children's disputes and the role of threats in peer interaction as well as in interaction in classroom settings. The aim is to examine how two children aged seven who are best friends at school use threats in pretend and real life frames in managing classroom dispute. The analysis focuses on one extended episode from a study of more 26 hours of video recorded classroom observations in a classroom in Finland. Despite their significance and occurrence in children's discourse, less attention has been paid to children's threats and their functions, and threats in pretend frames have not been the main focus in the studies of children's disputes (see Benoit 1983; Church 2009; Church \& Hester 2012; Danby \& Baker 1998b; Goodwin \& Goodwin 1987; Goodwin 1990 \& 2007).

Analysis shows how there is not any specific topic in the dispute, and it reveals how the boys switch from the pretend frame to one other or to a real life frame, and how different realities and multiple role taking are omnipresent in children's interaction. This article also shows how, with the use of threats, boys bring issues related to their subculture and out of school activities to the fore, such as video games, and invoke moral orders of what they are allowed, or not, to do inside the frame that they are in. Before proceeding with the detailed analysis of threats in pretend frames, this next section 
discusses prior research of children's threats and disputes, and the methodological considerations of this study.

\section{Disputes as interactional achievement}

Disputes are mutually constructed achievements indexing that the other person has done something bad, inappropriate or unwelcome related to the other person, or when one person attempts to influence how another should behave (e.g. Hay and Ross 1982; Danby \& Baker 1998). As Antaki (1994), Cromdal (2004) and Maynard (1985) have uncovered, usually dispute consists of two contradictory positions established over three-turn sequences. The three-part-structure includes an antecedent event, an opposition and a reaction to the opposition (Maynard 1985), or claim, counter claim and a following expansion (Antaki 1994, Cromdal 2004).

In disputes, as well as all forms of interaction, participants orient to the sequentality of interaction, i.e. the way in which actions and utterances are ordered (e.g. Schegloff 2007). Each turn in conversation is understood as doing something and it is consequential for the ongoing social action. Maynard demonstrates the sequential structure of children's disputes which begins either verbally or nonverbally prior to the dispute. As Antaki (1994) and Danby \& Theobald (2012) point out, it is the subsequent talk that makes what has been said a disputable matter or not. The following excerpt provided by Danby \& Baker (1998b) shows how the second speaker constructs the first speaker's turn as producing a point of dispute:

\footnotetext{
A: $\quad$ Go and make her (nodding toward C) feeling better.

B: I didn't do anything.

A: $\quad$ Yes, you did.

B: No
} 
Dispute begins on the second participant's turn with an opposition and continues until opposition ceases (e.g. Church 2009). The disputability of the first turn is defined in the second turn; for example, whether some action is determined an insult or tease always depends on its recipient and the frame at hand (see pages 6-7). Although the disagreement is dispreferred activity in adult conversation with the use of delays and prefaces mitigating the disagreement (Pomerantz 1984), in children's disputes oppositional actions tend not to be dispreferred (e.g. Church 2009: Goodwin 1982). Children usually display opposition towards signalling opposition immediately and without mitigation (Goodwin 1982: Goodwin, Goodwin \& Yaeger-Dror 2002); the clear orientation is towards highlighting rather than mitigating opposition. According to Goodwin et al. (2002), children display an orientation towards sustaining and promoting, rather than resolving the dispute, and they suggest that the tendency to display opposition is as an important feature of children's peer culture. This definition works as a point of departure, as the focus in this paper is not on the dispute format, but rather on the threats.

\subsection{Threats as part of disputes}

Threats are forms of social action with the purpose to influence the behaviour of another. They are types of argumentative moves expressing the intention to punish the receiver or withhold an object/action to achieve the purpose of altering receiver's behaviour (e.g. Benoit 1983; Church 2009). The idea of threat is performative ${ }^{1}$, to make some action happen. It means that threat-maker's intention must be perceived as an intended threat by the recipient (Benoit 1983).

Participants mutually construct the threat and the response unit. According to Sacks (1987), threats are an initiating action, and the threat-recipient must produce an appropriate response to the threat to complete the adjacency pair ${ }^{2}$. The second part of adjacency pair usually is a response to some action or state of affairs that made the threat itself conditionally relevant. For example, the receiver may

\footnotetext{
${ }^{1}$ The term performative is drawn from J.L. Austin's work, "How to do Things with Words" (1962)

${ }^{2}$ Adjacency pair consists of two turns where the first sets up an expectation to the second turn (e.g. Schegloff 2007).
} 
accept the threat and revise the behaviour that provoked the threat, consider the threat as lacking force and reject it, or produce a reciprocal threat. This preferred response intended by the threat maker is for the recipient to perceive that the threat carries enough force, and that the expressed intention is enough to alter the disputant's behaviour. To respond appropriately, the receiver may accept the threat and alter the behaviour that provoked the threat, reject the threat as unreal, or engage the speaker in competitive escalation by producing reciprocal threat. If the threat lacks power, however, the recipient will generate a response that addresses the deficient character of the threat as produced (Benoit 1983; Church 2009.)

Threats are usually placed after a series of dispute sequences. Church and Hester (2012) showed how threats are used to bring about the close of the child dispute in favour of the threat-maker, such as "If you don't give me one of those, you can't come to my party". They have uncovered the basic structure of the threats, which usually contains two parts related conditionally: an if-clause and a thenclause, if-clause referring to something what the threat-receiver is doing or not, and a then-clause referring to what will happen. The then-clause is related conditionally: the occurrence of the second is conditional upon the occurrence of the first I. e. if a recipient continues the action or does not do the required action, the negative consequences will be affected by the speaker (Church \& Hester 2012, 245; Hepburn \& Potter 2011.) However, unlike threats in 'real' frames in which threats are brought to a close quickly as shown in Church \& Hester's (2012) or Potter \& Hepburns's work (2011), the episode studied here shows a pretence frame where the threat making continues and is escalated over several turns.

Benoit (1983) categorised children's first-pair threats into four different categories: harmful threats, unspecified outcome threats, withhold-threats and tell authority-threats. In harmful threats the interactant threatens to physically hurt the recipient, whereas in unspecified threats the specific intent of the interactant is not clearly specified. Withhold-threats carry a refusal to continue a desired action or object and tell authority -threats carry an adult intervention that would sanction the recipient. In the case analysed in this article all other threats are utilized apart from telling on-threats. 


\subsection{Frames as a resource in children dispute}

This study is unique because it examines children's threats in the contexts of pretend frames. Frames, as features of spoken language, can be characterised as temporary, situational definitions of social actions providing a way for participants to interpret and guide the social situations they are in (Goffman 1974). When participants begin to engage in interaction, their actions become interrelated in systematic ways so as to bring about a social event in which the 'frame' of meaning may not always be clear from the beginning. Thus, the first question participants face when attending to any situation is "What is going on here?" (MacLachlan \& Reid 1994). Many actions cannot be properly understood without a specific frame; for example jokes, dreams and theatrical performances need their frames to be understood (Goffman $1959 \&$ 1974). By jointly deciding what practice is taking place at the given moment, participants also agree on the rules, structures and practices that guide that practice at hand (Goffman 1974: Streeck 1986, 71; Aarsand 2008). As Goffman (1959; 9-10) explains it: "Together the participants contribute to a single overall definition of the situation which involves not so much a real agreement as to what exists but rather a real agreement as to whose claims regarding what issues will be temporarily honoured." Thus, frames are products of social interaction.

Frames should not be seen as static or given once for all. As well, there can be frames within frames whereby a subset of the interaction can be bracketed as a separate embedded episode (Goffman 1974): in the case analysed in this article, the boys at the beginning of the exchange are in at least two frames: they are in the classroom lesson and they know that the teacher will appear at any moment. Their body positions and gaze display engagement to the lesson frame; the boys are sitting on their desks and it looks like that they are reading their book as the other children (see Figure1 on page 10). Also they have established a second frame, the dispute frame, and they know how activities are supposed to be performed and understood in this frame. Within the dispute frame the boys also invoke and switch between different frames, of which some are pretend and some related to their 
personal history as friends. With the use of these pretend frames, they bring issues related to the outof-school activities to the fore. Thus, one situation, such as the classroom dispute can consist of overlapping, complex and multiple frames.

Pretence as social form of action is a frame, and participants are able to understand that their actions are pretend actions in this specific frame. Pretence is a socially mediated activity, constructed and negotiated through talk (Goldman 1998). According to Sidnell (2011), participants orient to pretence/make-believe as a normatively organized set of practices. The boundaries between the pretend frames and everyday social life are dynamic and permeable, especially in children's everyday lives (Sawyer 1999). Children are shown to be competent to switch seamlessly between pretend and real life frames, thus the pretence can work an omnirelevant resource (Sacks 1995) in children's social life.

Pretence is a common and mostly child-initiated feature of children's culture (Grieshaber \& McArdle 2010). In peer action children learn to play different roles, create new meanings and develop situated meanings with the phenomena at hand. Cobb-Moore, Danby and Farrell (2008) have researched how children built mutual and pretend understandings of places and objects (2008). They uncovered how children used pretence to define places and objects as something other than what they were, and how they developed rules and restrictions based on pretence. Sidnell (2011) has shown how epistemic rights work in children's pretend play, and how children invoke moral rules as assumed to govern participants' conduct within activities of make-believe. Björk-Willen (2012) has shown how different roles are argued and negotiated by the participants in children's family role play, and Sheldon (1996) describes how a third girl tries to enter to dyadic play by making the pretend character relevant to the on-going action within the logic of the pretend frame.

Departing from these studies, in the present data, pretense is invoked in the middle of a dispute. The analysis presented in this article shows how the participants take pretence as a resource to threaten and defeat the disputant. Disputes during children's game playing have been investigated, but not 
how game playing is used as a resource while not playing (Aarsand \& Aronsson 2009; Davidson 2012; Sjöblom \& Aronsson 2012).

\section{The study}

The analysis has been carried out with the methodological framework of conversation analysis (see for example ten Have 2007) and ethnomethodological studies (e.g. Garfinkel 1967; Heritage 2001). Ethnomethodology is concerned with studying interpersonal social interaction, and premised upon the fact that social structures are locally produced and maintained through practices of the participants (Garfinkel 1967). Local accomplishment of practices is called social order. Social order is not a precondition of interaction, but generated and maintained moment-by-moment among the participants. If some participant breaches locally constructed organization of appropriate actions, it reveals the local moral order, moral order in interaction (e.g. Bergmann 1998). The moral order is deeply woven into ordinary activities in which they are produced, rather than being independent or outside of them.

Conversation analysis (henceforth in CA), a form of ethnomethodology, pays attention to locally produced social and moral order(s). CA is a micro-analytic examination of conversational practices that produces fine-grained descriptions of how talk and embodiment in interaction are carried out (e.g. Hutchby \& Wooffit 2008; Psathas 1995). The focus of CA is not the interactants' linguistic abilities, but rather on their methods and procedures they use to accomplish social interactions and to maintain and construct social order. These can be uncovered by studying the sequential organisation of talk, i.e. the way in which actions and utterances are ordered (e.g. Schegloff 2007). Each turn in conversation is understood as doing something and it is consequential for the ongoing social action. Thus, the analysis is based not on what participants are intending to do, but on what actually happens when participants engage in practical activities and making sense of them (Maynard 1985). 
The data of this study are drawn from a larger study of a corpus of 26 hours of video recorded classroom interaction. As well as video recordings, the data gathering included ethnographic memos and teacher interviews, to provide contextual details of the setting. The data were gathered in the southern and central part of Finland in urban public schools. Two video cameras on tripod were placed to video-record all the interaction in classroom. The author was present and kept diary of observations, and minimized her participation to the on-going action by taking a role as bystander.

The selected episode contains a dispute between two boys in first grade, Osku and Viljo ${ }^{3}$, in the middle of the school year. This specific case was chosen as it includes multiple resources that the boys used and illustrates how the same shared and multi-layered frames made the dispute possible alongside the formal school work. The selected episode was the longest dispute among the data and illuminated most clearly how threats can be framed in children's disputes. Figure (on page 10) shows how the boys and other children are positioned in the classroom. Osku and Viljo have just arrived from the library bus ${ }^{4}$, and other children are arriving one by one to the class at this time when the dispute unfolds.

The key participants, Osku and Viljo, are 7-year-old boys who are regular playmates and best friends at school ${ }^{5}$. The classroom lesson is about the mother tongue and literature, and the children are told to borrow a book from the library bus and then go back to the classroom to read it. They are advised to borrow a book related to their reading skills. In this episode, the teacher is not present, but will arrive from the library bus in any given moment. There is no key topic on the dispute, but two parallel offences that have triggered the dispute. Osku borrowed a Maisy Mouse book ${ }^{6}$ from the library bus and was ridiculed by Viljo. In accordance with the ethnographic memos by author, Viljo ridiculed Osku by saying that Maisy Mouse books are aimed at 'babies'. On the way back from the library bus to the classroom Viljo slipped over and Osku laughed about it. The dispute episode continued for over six

\footnotetext{
${ }^{3}$ Names are pseudonyms.

${ }^{4}$ The library bus is a bus with books available to borrow which stops at the school approximately once a month. Children are advised to borrow a book from it for a mother tongue and literature lesson.

${ }^{5}$ According to the ethnographic observations by the researcher.

${ }^{6}$ Maisy Mouse is a fictional animal from the picture book series created by the British illustrator Lucy Cousins. It is translated also into Finnish and the character is called as Maisa-hiiri.
} 
minutes and did not end until the teacher's intervention on arrival in the classroom. The boys had not been seeking a resolution themselves, and the teacher closes the episode.

\section{Analysis and results}

The analysed episode begins when the boys are sitting on different sides of the class having eye contact with each other (see Figure 1 on page 10). They are holding and browsing their library books. There are also other pupils in the classroom, but other than one pupil, Tatu (see Figure 2 on page 11), do not intervene or pay attention to the dispute. The situation is a kind of cross conversation, where the key participants are talking to each other. The data are transcribed by using Jefferson's transcription conventions (see Psathas 1995, and appendix 1 for a list of the conventions used in this paper). The transcription is translated from Finnish into English. Translation can sometimes be problematic (see also Nikander 2008), because Finnish is dissimilar to English, and difficulties are due to typology and idiosyncratic differences. In addition, features of child language might sometimes be challenging in order to find the similar meaning carrying word. However, the transcription has been done carefully in order to maintain the conversational style, chosen words and the tone of voice the children use in order to convey the message, and some details are pointed out in footings. English translation with line numbers is in after Finnish one in bold.

Figure 1. 


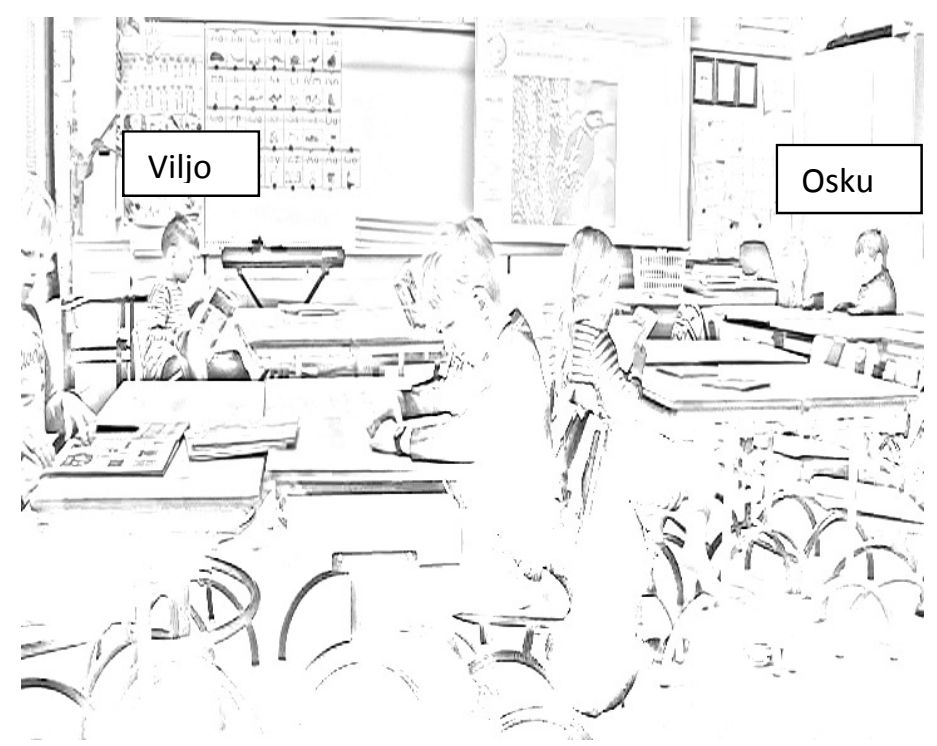

Fig. 1.Viljo and Osku sitting on their desks and having a dispute.

\section{Excerpt 1: Threats of violence in video game frame}

Excerpt 1 shows how the first pretend frame, video game world, is invoked by a threat, and how that threat is responded to by reciprocal threat. Before it, the boys have sat down at their desks and Osku has started to read, although reading aloud is usually discouraged.

Osku: Viljo haukku mu- kirjaa.

$1 \quad$ Osku: Viljo was trashing $\mathrm{m}$ - book. ((Says to Tatu in the corridor))

2 ((Both boys walk to their desk.))

Osku: Vii-sas. Saa- (--)

3 Osku: Cle-ver. Saa- (--) ((Starts reading aloud the book he borrowed))

Viljo: Mä lähetän viiruksia (--).

$4 \quad$ Viljo: I will send viruses (--).

Osku: Okeei. (1.0) No paa vaan. Sitten sulle käy huonosti.

5 Osku: Okaay. (1.0) Go ahead. Then something bad will happen to you.

Viljo: No miten?

6 Viljo: Well what?

$7 \quad($.

Osku: No: en kerro sulle.

8 Osku: Well: l'm not going to tell you.

Viljo: $\quad \uparrow$ No ei oo pakko mut ku ei se mitää auta et- sä luulet vaan.

9 Viljo: $\uparrow$ Well, you don't have to but it doesn't help it is 
Osku: No auttaa.

11 Osku: It does help.

Viljo: Mä oon yhtä vahva sun kanssa

12 Viljo: I am as strong as you are.

Mää oon Osku yh- vahva yhtä vahva ku sä joten (.) sun (.) [hyökkäyksess

13 I am Osku as- strong as strong as you are, so (.) your (.) [attacks are

Osku:

[Et oo

14 Osku:

[You are not

Viljo: ei paljo a- auta.

15 Viljo: are u-useless.

Osku: ET oo vahvempi ku ku minä.

16 Osku: YOU are not stronger tha- than I.

Viljo: Oon. Mä katon tätä yksin.

17 Viljo: I am. I will look at this alone, by myself.

$18 \quad$ ((points the book in his desk and starts browsing it))

$19 \quad(2.5)$

Osku: Oke. Sä e- (.) kato vaan ja se on ihan huono kirja.

20 Osku: Oke. You don't (.) well go on and it is such a bad book.

At the beginning of the dispute two threats are posited, in lines 4 and 5 . The threat is initiated by Viljo, who selects Osku as the addressee with his gaze and then produces a turn which takes viruses inside of video game world as a resource for doing a threat. ${ }^{7}$ Thus, the game frame is established at first time and happens again later on in the dispute (see Excerpt 2). The practice of sending viruses is essential in many of the video games (e.g. Linderoth 2012), and in the games players have to have forces to defeat the other(s). The shift to the video game frame is done without any closings or sidesteps to the previous topic (cf. Jefferson 1984).

Osku receipts the threat and, as defence poses a conditional, reciprocal threat against Viljo. Osku's threat is unspecified (Benoit 1983, see also page 4-5) and universal: then something bad will happen to you (line 5), which invites follow up questions. This threat includes the 'if and then clause

\footnotetext{
${ }^{7}$ Viruses are taken inside the videogame, although the field notes are not detailed enough to name the game.
} 
structure' (see page 5; Church \& Hester 2012; Hepburn \& Potter 2011), but the meaning is not to alter the recipient's behaviour, but to complete the threat if the recipient will complete his. Thus, Osku's reciprocal threat is like a warning of a punishment if Viljo accomplishes his threat. With the use of the grammatical construction something bad will happen, he downplays his agency and it can be seen as making the issue more subject to general rules about what typically happens, an upshot that Osku has no control over (Hepburn \& Potter 2010).

Contrary to Viljo's threat of viruses (line 4), Osku's threat is treated as a possible real life threat. Viljo wants to have more information about the threat (line6), but Osku refuses to tell more, which is a resource for holding one's power in the dispute (line 8). Viljo receipts Osku's threat and treats the it as nothing to be scared of and rejects it: but it does not help, it is that only you think so (lines 9 \& 10). By invoking the term of believability, Viljo challenges whether the threat actually could be accomplished. Unspecified consequence threats are vague usually because they are not perceived as such as readily. Osku tries to keep his threat alive and opposes Viljo: it does help (line 11).

Viljo's turn on line 12 presupposes that Osku's threat is a warning that is somehow related to physical harming and attacking. He characterises himself as strong as Osku and thus capable of defending himself in real attacks: / am Osku as- strong as strong as you are, so attacks are are u-useless. (lines $13 \& 15)$. Physical strength is related to these issues, which are typical features of the masculine friendships (e.g. Danby \& Baker 1998a; Walkerdine 2007). In this episode, Viljo claims himself to be as strong as Osku, but Osku denies Viljo being physically stronger (or more powerful) than himself, which Viljo resists. In his next move (line 17-18) Viljo denies collaboration and expresses his willingness to look at the book by himself. Thus Viljo's book is talked into being (Bateman 2011; Heritage 1978). His announcement / will look at this alone, by myself indicates that there has previously been orientation to collaborative reading. This turn of action and book browsing indexes Viljo's attempt to withdraw from shared dispute action and, after a long pause, Osku agrees. This action does not stop the dispute, although it does pause the dispute sequence. Viljo's book is the next topic of the dispute. 


\section{Excerpt 2: Escalating threats in video game frame}

Excerpt 2 is a continuation of the previous excerpt. Viljo's book is now talked into being (Bateman 2011; Heritage 1978) and becomes as object with semiotic meanings. The roles of mocking a book are now opposite. After it, the boys shift to video game frame again and construct threats. This episode highlights how knowledge of the game works as one of resources, because both boys have knowledge about the game and they both use it as a resource. In the previous excerpt, physical strength was invoked as one resource to defeat the disputant, now knowledge and competence in video games is drawn as a resource. Viljo escalates his threats from viruses into badass viruses, indexing the shared history with game playing and illustrating how the believability of the threat is challenged.

Osku: Oke. Sä e- (.) No kato vaan ja se on ihan huono kirja.

21 Osku: Oke. You are no- (.) Well go on and it is such a bad book.

Viljo: Tää on tosi hyvä. Tääl o- tääl o- Osku=

22 Viljo: This is really good. Here is- here is- Osku=

Osku: =Se on ihan huono.

23 Osku: = It is very bad.

Viljo: Miks sä oot halunnu tän?=

24 Viljo: Then why did you want this?=

Osku: = Se on ihan $\uparrow$ huono.

25 Osku: = It is such a $\uparrow$ bad.

Viljo: Osku (.) $\uparrow$ miks sä sitten sanot et sä olisit kerran halunnu ${ }^{\circ}$ tätä?

26 Viljo: Osku (.) $\uparrow$ why do you say that once you wanted to have ${ }^{\circ}$ this ${ }^{\circ}$ ?

$27 \quad(1.5)$

Osku: No nii: (.) mut enempää mä en halunnu (.) kun et ää (.) sulle kävi noin.

28 Osku: Well: but nothing else I wanted (.) than emm (.) that that happened to you.

30

Osku: Njää.

31 Osku: Njee. 
Viljo: Nii:, hyvä asia et sä et haluu.

33 Viljo: Yeah: good thing that you don't want.

$34 \quad(1.5)$

Osku: Hyvä asia et se oli iha $((--))=$

35 Osku: Good thing that it was such $((--))=$

Viljo: =Nii, hyvä asiat, et se oli iha surkee.

36 Viljo: =Yes, good thing that it was so bad.

Osku: Hyvä asia et se oli [huo-

37 Osku: Good thing that this was [ba-

Viljo: [Hyvä asia et--

38

Viljo:

[Good thing that-

Osku: ((--)) haukkuu tätä kirjaa.

39 Osku: ((--)) can't mock this book. ((Points at book in his hand.))

Viljo: Sit sä et saa haukku tätä.

40 Viljo: Then you can't mock this.

41 (.)

Osku: Haukum mä.

42 Osku: I can.

Viljo: Voim mäki haukkuu tota.

43 Viljo: I can also mock it. ((Beating with fingers.))

$44 \quad(0.5)$

Viljo: Mä pistän tautisia vi:ruksia jotka tuhoo su vaunun.

45 Viljo: I will send badass vi:ruses which will destroy your wagon.

$46 \quad($.

Osku: Eet pysty.

47 Osku: You can't do that.

Viljo: Pystyn.

48 Viljo: Oh yes I can.

No hei ei sun Osku mitään auta ku viirukset menee= There's nothing you can do Osku when the viruses.=

Osku: =No ei sunkaan mi kään auta.

50 Osku: =There's nothing you can do either.

51

Osku: Sun ei auta mikään.

52 Osku: There isn't a thing you can do.

53

Viljo: Mä laitan Osku niin paljo joukkoja hyökkäykseen et vaikka sä

54 Viljo: I will occupy Osku so many troops that even if you lähetät viiruksia niin vaan se ei auta. 
send viruses, it won't help.

Osku: \$Jihaa, jkää(h)ääh, jkää(h). $\uparrow$ Nii haus:kaa ku sä fliukastui:t_.\$

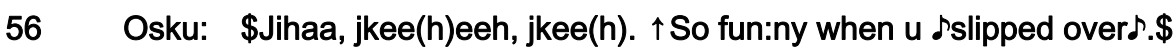

Viljo: _ $\uparrow A i$ jaa mut sit mä teenkin sulle pienen ১jeku:n!॰

57 Viljo: $\uparrow$ Aha, in that case I will play a little. \& pra:nk $\delta$ on you !

$58 \quad(1.5)$

Osku: Okei, sit mä teen sulle pienen jekun myös.

59 Osku: Okay then I will play a little prank on you as well.

Viljo: No tee!

60 Viljo: Go ahead!

Osku: Minkä?

61 Osku: Which?

$62 \quad(0.8)$

Viljo: En kerro sulle.

63 Viljo: Not going to tell you.

Osku: Ai jaa paitsi mä en silti aio uskoo.

64 Osku: Oh, yes but I don't believe that.

Viljo: $\quad$ No ei oo $\downarrow$ pakko mutta ((--)) Jos sä värität niin paljon

65 Viljo: You don't $\downarrow$ have to. But $((--))$ If you colour so much väärin niin mä en väritä sitten. Jos sä jos sä sanot mulle

66 wrong then I will not colour ${ }^{8}$ at all. And if you say to me että (0.5) että ä: hei väritä tän nii sillon mä en väritä. that (0.5) that ä: hey please colour this so then I won't colour.

In the previous exceprt Viljo wanted to look the book by himself, Osku accepts it and makes a negative evaluation of Viljo's book. Because the lesson is mother tongue and literacy, and the children are advised to read their books they borrowed, mocking the book the other has chosen is a practice one can do in order to tease the other interactant. In this case book can be seen representing children's reading competencies. Viljo was mocking Osku's book choice in the library bus positioning the book as childish, book aimed at babies (line 1 in excerpt 1, see also page 8). Thus when disputing at school, schoolbooks can be resources children can utilize in the interaction for their own purposes, and book as material object having semiotic meanings. Now the roles of mocking books are reversed; Viljo's mocking of Osku's book was an action that triggered the dispute, but now Osku mocks Viljo's

\footnotetext{
${ }^{8}$ Colouring is related to computer game
} 
book. Thus Osku gets back at Viljo. Osku makes evaluations of the book: Well go on and it is such a bad book (line 21 ) and then in lines $23,25 \& 37$. The evaluation is every time same: bad book. Usually in disputes, the speaker's new turn is justified by an entity, which is more concrete than his or her previous turn. For example, want can upgrade to obligation in the next turn (Danby \& Baker 1998a; Pomerantz 1984). In this case however, Osku's assessment only continues with repeating the insult about the book, 'a bad book' without providing any justification for this assessment. A justification might be hard to give, because Osku has been interested in the book. Thus, book is talked into being as having semiotic meaning related to children's competencies and ownerships, and making negative references what belongs to other interactant is a way to manage dispute.

Viljo defends the book with an opposing assessment in line 22 by considering the book "as a good book". Usually in children's disputes, the second opposite assessment is stated without any mitigation. In line 23 Osku repeats his assessment and Viljo challenges it by referring to Osku's previous interest with the book (line 24). This utterance works to simultaneously contradict Oskus's previous action. Because this utterance is a reference to a previous event, and the boys have talked at least once before about the book, it seems difficult for Osku to answer the question. Viljo's question is followed by a pause and Osku starts his turn with pre-entry, with the particle 'well', usually a mark of dispreferred action (e.g. Pomerantz 1984). Osku does not give an answer and reverts to Viljo's slip: Well: but nothing else I wanted (.) that emm (.) that that happened to you. It is obvious that Osku was not the offender in Viljo's mishap, but the way he packages his words gives an impression of pleasure and suggestion that the mishap, while bad to Viljo was favourable to Osku. This turn also positions participants as 'the teased' and 'the teaser' and Osku is teasing intentionally. The dismissal relates to a previous discussion about comparing power and is interpreted as Osku's attempt to be more powerful than Viljo. This excerpt illuminates how situational status and power are not given by the boy's competencies; instead, they are under negotiation.

In line 39 Osku states a rule that Viljo is not allowed to mock the book. The rule is situational in that it is to be applied in the dispute locally. Stating this rule is reverting to the beginning of the dispute, 
because in the course of the dispute Osku has been the only one in mocking the book. Viljo responds with stating a similar kind of threat (line 40): Then you can't mock this book. Viljo's turn is a repetition of Osku's rule with the use of the same words. Thus prior action provides resources that are selectively reused in the next turn. Prior speakers words are also used against him (see Goodwin 2013). Like in excerpt 1 , beginning his rule with then means that the meaning of his rule is conditional upon the occurrence of the rule first stated (Danby \& Baker 1998a). But Osku does not accept Viljo's rule and refutes: you can't changes to / do can. After that, because Osku refuted Viljo's rule, the existence of Osku's rule is also overruled (lines $39 \& 40$ ). In line 43 Viljo packages his words in the way which gives an impression of choice: / can also mock it, continuing to assert his agency in this matter.

On line 45, Viljo again draws on resources from the video game world and threatens Osku with viruses. The object of terror is a van in the game world: I will send badass viruses which will destroy your wagon. Viruses are resources that Viljo deploys in order to show that, after enforcing the threat, Osku will be unable to play the game to the best of his ability. Viljo escalates his threat: previously he was threatening with viruses, now he threatens with badass viruses and explicates the consequences. Now the third frame is established again: boys are inside the classroom lesson frame, inside their peer culture and friendship frame and inside the pretend video game frame. The shift to the video game frame is again done without any closings or sidesteps to the previous topic.The pretend frame of the video game world is invoked, although the game is not present and threats can only be accomplished in the future.

The boys' talk indexes that they have played video games together and have a shared knowledge of their objects in game world. Viljo's threat is followed by an immediate refutation by Osku: You cannot do that ((or You are unable to do that)). Viljo's utterance in line 54 escalates the game situation from threats into a fight strategy I will occupy by so many troops that even though you, will send viruses, it does not help you. Viljo has been threatened Osku with viruses in the beginning of the dispute (line 4) 
and again here (45). Although Osku has not been threatened with viruses, in line 54 Viljo posits Osku as virus sender portrays how he will beat Osku in a game attack.

Osku has no counterpart to deploy and he reverts to Viljo's slip and the beginning of the dispute: It was so funny when you slipped over (line 56). The same thing happened in line 29: when Osku was unable to respond in kind, he took Viljo's slip as a resource against Viljo and in favour of himself. Thus, the boys have switched to another frame within the dispute. Viljo responds with another threat and launches the term prank: In that case / will play a little prank on you. Osku responds with a counter attack / will play a little prank on you as well. Presumably the prank is not related to a video frame and it is in the same physical frame as the slip. Line 65 shows a new threat in the context of video game world in terms of colouring in computer game ${ }^{9}$. Viljo's threat is one of withdrawing from collaboration and friendship in playing at least this particular video game. Thus Viljo escalates his video game world threats from viruses and badass viruses into withdrawing from collaboration in playing the game.

Excerpt 3: Escalating threat in the real life frame and third party intervention

\footnotetext{
${ }^{9}$ Coloring is an activity in some virtual games.
} 


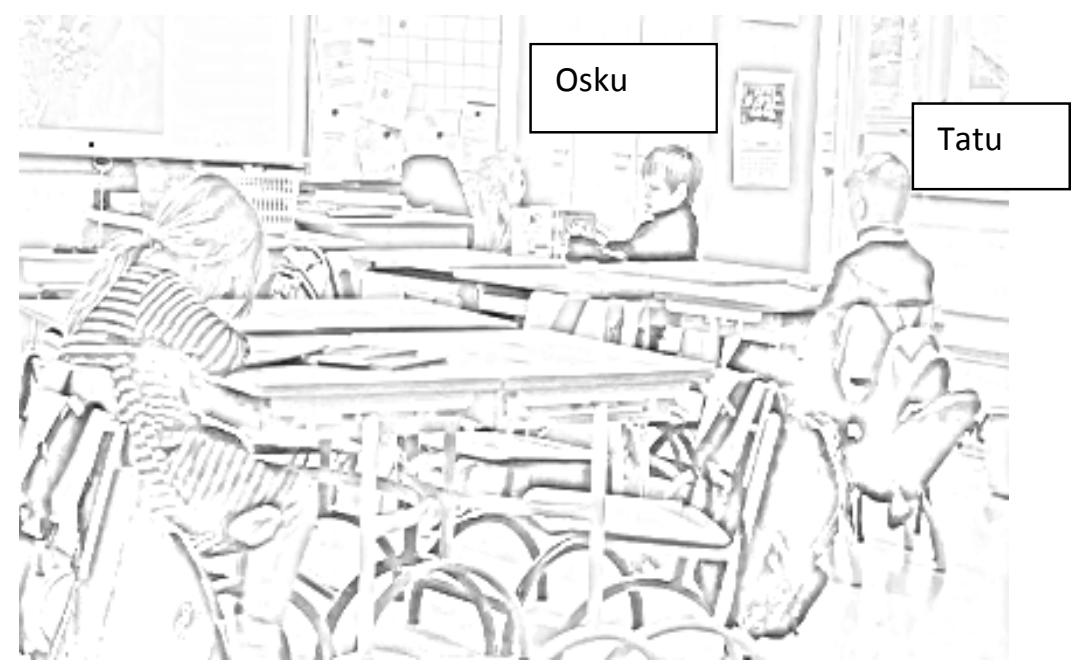

Fig. 2.Tatu sits close to Osku.

In this third excerpt, the boys are no longer inside the pretend frames; instead they shift to real life frames. They invoke a membership to category of friendship and thus friendship can be understood as omnirelevant (Sacks 1995) in the sense that it operates as a resource to be invoked when needed. In the excerpt Viljo escalates his threat again, withholding friendship, which triggers Osku to call Viljo as a lousy friend. This leads to third party intervention, by the third participant Tatu who has overheard the dispute because he is sitting very close to Osku (see Figure 2) and entered the classroom at the same time with Osku and Viljo. Tatu becomes disregarded. Interactants enact their personal relationships in their current interactions.

Viljo: Ei olla enää kavereita.

76 Viljo: We are not friends anymore.

Osku: Ollaan.=

77 Osku: Yes we are.

Viljo: =El olla.

78 Viljo: = NO we are not.

Osku: Surkee kaveri.

79 Osku: Lousy friend.

Tatu: Osku.

80 Tatu: Osku.

Osku: Iha surkee kaveri. 
81 Osku: Such a lousy friend.

Tatu: Sä et sitä (.) Osku päätä et onks se surkee kaveri.

82 Tatu: You can't (.) Osku you can't decide whether he is a lousy friend or not.

Osku: Surkee kaveri.

83 Osku: Lousy friend.

Tatu: Jos sä haukut toista nii ne ei enää itte oo sun, Osku, jos sä haukut toista.

84 Tatu: If you mock somebody then they don't themselves be yours-,

85 Osku, if you mock somebody.

Osku: Surkee kaveri, surkee kaveri. Ihan SURkee kaveri.

86 Osku: Lousy friend lousy friend. Such a LOUsy friend.

$87 \quad(2.5)$

Osku: Ihan surkee kaveri.

88 Osku: Such a lousy friend.

At this point the boys shift from the video game frame to real. Viljo draws upon the category of friendship explicitly and shows willingness to end the friendship by saying: We are not friends anymore (line 76). Thus the category of friendship has an omnirelevance (Sacks 1995) for the dispute and now it is explicated. By talking their friendship Viljo invokes their both co-membership to the friendship category which has served as making frame to the dispute. Thus, what boys have done or said during the dispute can be connected to their identities as friends to each other.

This announcement We are not friends anymore can be seen as a threat too (Benoit 1982), and it has its real life consequences: withdrawing from or withholding the friendship. A willingness to be a friend is a form of social control because friendship is always mutually created and friendship is a highly desirable for children (Bateman 2010; Church 2009; Corsaro 1985). Now the threat is real and can be completed at the moment. As many times earlier, the next turn is just a quick opposition as well as rejection of the threat: Osku's utterance shows will to the continuation of the friendship: Yes we are (line 77) although right after that he is name calling Viljo as a lousy friend. This raises a question of function of the dispute: is it very serious business or more some kind of linguistic play, or play fight 
that neither wants to lose. The ending of the friendship could be an efficient closure to the dispute, but it just goes on. By continuing the talk, the boys also display their alignment to be involved in this interaction. It also supports an idea of dispute in the frame of friendship. It seems that despite the threats and insults, the dispute does not lead to breach in the friendship. ${ }^{10}$ In addition, the boys use the pronoun we. In previous research it has found that with the use of pronoun we, children verbally affiliate themselves with another person in order to make it observable that such an affiliation, or friendship, exists (Bateman 2012). They could have also used pronoun I, like / am not your friend anymore. But using the plural we -form it is possible to display collaborative action and a type of alignment to the ongoing action.

However, Osku's categorization of Viljo as a lousy friend (line 79) is an insult in real life moral order. With the use of 'lousy', he displays that the action is not acceptable for a friend and thus Viljo is now nominated as lousy friend. It also downgrades Viljo's status as a friend. Tatu takes it seriously and makes a third party intervention which has been found typical in conflict situations (Maynard 1985). Osku and Viljo have shifted from the pretend frames to the real life frame and Tatu displays by his intervention that the insults and consequences are real. In addition, the insult gets to the personal level. While in pretend frames insults and consequences are less stable and not real in the same way, in real life the consequences are different. Tatu sits very close to Osku (see Figure 2 on page 11) and has heard the dispute before as a bystander. He tries to get floor and attempts to bring a part of the moral order or real life to bear on the dispute. Tatu's utterance (line 82) is addressed to Osku: You can't decide that whether he is a lousy friend or not. In his utterance, Tatu does not direct oppose Osku's evaluation, but denies Oskus' capability to make his evaluation.

Tatu's turn makes visible a particular moral order. One reason why he took part might be that now the insult is made in a real life frame and towards a person, not towards a book or wagons as previously. His intervention can be seen as an attempt to restore the moral order of the traditional classroom

\footnotetext{
${ }^{10}$ Based on the ethnographic observations by the researcher. This dispute occurred in the morning and later on the same day the boys were playing together during the breaks.
} 
framework, but he does not get a response. The alignment proposed by the third party is seen as an offer of collaboration that may be either accepted or rejected with the offers generally accepted (Maynard 1985). However, Tatu remains outside the dispute, because neither Viljo nor Osku responds to him. Even though Tatu directs his opposition to Osku, Viljo does not solicit support or alliance 'two against one' from him.

Usually other friends are a resource that children turn to when they need help, but the reason why Viljo does not do that might be that because Osku and Viljo are friends, they want to settle and find the winner by themselves. Also seeking assistance from an external ally might indicate that the participant seeking coalition is not strong enough to control the situation and the other disputant. In addition, with the use of we-term, the boys have also established a dyadic friendship in which is not space for the third party (see Bateman 2012). At this time Viljo does not respond and for example not categorize Osku as a lousy friend too. Osku disregards Tatu's turn by repeating and escalating his evaluation of Viljo: Lousy friend, lousy friend. Such a LOUsy friend (lines 86-88).

\section{Excerpt 4: Threats in a mass fight frame and drawing on other persons as a resource}

In this excerpt the boys shift to pretend frame, although the participants mentioned in this frame are real. In the previous example the third party, Tatu, was not acknowledged. Contrary to that, now the boys draw external participants to the dispute in a pretend frame and both accept that. With this resource, they start to verbally construct a mass fight, and Viljo constructs a strategy how to defend and attack. Viljo escalates his threats again. The physical mass fight frame also echoes the video game fight. In this episode video game reality is transformed into real life but in pretend frame.

Osku: O mulla paljo a a muitaki kavereita. (.) Ja ne voittaa sut.

90 Osku: I have so many other friends too. (.) And they will beat you.

Varsinkin Eeron koska (.) nehän tota ä niinku edestä sivusta: ja 
92 [from the front

Viljo: [No nii

93 Viljo: [Well, yes

Viljo: mut Osku, mä meen siihen väliin silleen et ne hyökkää ensin muhun=

94 Viljo: but Osku, I will interfere in the battle in a way that they will

95 attack me at first=

Osku: =Aijaa.

96 Osku: =All right.

Viljo: Ja Eero ehtii hyökätä nopeesti et ne ei voi tehä mitään.

97 Viljo: And Eero has time to attack so fast that they can't, can't do anything.

Osku: Mä voitan sut ekaks.

98 Osku: I will beat you at first.

Viljo: No nii mut Osku, ku sä tuut mu eteen niin mä heitän sut potkasen

99 Viljo: Yes, but Osku, when you will run to me I will throw you I will kick you I will silleen ku sä juokset mua päin nii mä potkasen sut silleen lentoon ja kick you like (--) and when you run straight to me, so then I will kick sit ku seuraavaks niin mä potkasen sen silleen lentoon. Ja sitte you so you will fly and then next I will kick you and next. seuraavalla ja sitä seuraavalla. and the next time and next time.

Osku: Paitsi t säe ees pysty.

104 Osku: Only that you can't do that.

Viljo: No pystynpä?

105 Yes, I do can?

Osku: Ne on nii voimaakkaita kuules.

106 Osku: They are so strong, you know.

107 (.)

Viljo: Nii, mut Osku sä et pysty tekee jotka liikkuu.

108 Viljo: Yes, but Osku you can't because they are moving.

Osku: Nii paitsi se ää - ((--))

109 Osku: Yes, but it ee $((--))$ No nii, mut tiäks mitä?

$110 \quad$ Well, but do you know what?

$111 \quad$ (.)

Viljo: No?

\footnotetext{
${ }^{11}$ In accordance with ethnographic memos by author, Eero is Viljo’s younger brother.
} 
112 Viljo: What?

Osku: Nii et sä et saa silti potkaista.

113 Osku: You are not, you are still not allowed to kick.

Viljo: Sit sä lennät jonnekin taivaan kuuseen.

114 Viljo: After that you will blow into the universe.

At this point, after positioning Viljo as a lousy friend, Osku puts effort into his name-calling and posits his other friends as better than Viljo: I have so many other friends too. (.) And they will beat you. (line 90). Osku's announcement of lots of friends is turned against Viljo and like in previous excerpt, to undermine the competence and significance of him. However, Viljo is still addressed as a friend although in last excerpt Viljo wanted to cease the friendship. The shift into pretend mass fight frame is done by utterances: And they will beat you. Especially they will beat Eero. Because they will attack from the front (lines 90-92). With this turn Osku starts to construct a fight and also invokes other person as a resource. Eero, the boy mentioned is Viljo's younger brother ${ }^{12}$ and now he is included in Osku's attacking plans and later in Viljo's defending and attacking plans (lines 94-95, 97). Both boys accept drawing external participants to the dispute. This time the shift to another frame is connected to previous frame, again without closing the previous topic, but the talk is related to friend competence and attacking which has been talk in previous frames.

Osku has, in the previous excerpt presented Viljo as a lousy friend and now Viljo's brother is placed in the same category, a target of threats and pretend attack. By downplaying a close relative of the other disputant might be a way to raise own stakes for Osku in the dispute, but Viljo draws upon his brother as a powerful resource in his favour too. Boys have compared themselves in relation to power and competing and now the theme of physical conflict is ignited. Osku describes his attacking plan and Viljo responds to that, especially how he will shelter his brother Eero (lines 94-95, 97): / will interfere in the battle in a way that they will attack me at first ((--)) and then Eero has time to run at you. Thus, Eero is not only a person to shelter but also an attacker in Viljo's strategy.

${ }^{12}$ In accordance with ethnographic interviews. 
Descriptions of offensive actions and defences go on. On lines 110 and 113 Osku constructs a rule of kicking "You are still not allowed to kick. ", which is the first time since the threat has been issued, and the action is prohibited. Viljo has upgraded his threat by indicating how he will kick Osku (lines 100101). Osku has also threatened Viljo with his attacks, but by banning the kicking he refuses to play so physical and brings up a rule to stop it. With a presequence in line 110: Well, but do you know what? He seeks a space to say it aloud. This utterance illustrates how there are also some sort of moral codes in boys peer culture which prohibits some kind of action. Viljo disregards Osku's rule and escalates his threat from kicking to kicking Osku to the universe (line 114).

\section{Excerpt 5: Teacher settling the dispute in institutional frame}

The dispute comes to an end after the teacher arrived. Very soon after the last excerpt the teacher enters the classroom. She hears the talk to the corridor and after entering the class she asks the boys an account for the noise. Viljo displays awareness that the teacher is not operating in their frame, instead in institutional frame and takes an account, which can be expected that teacher aligns with him. Osku is told to apologize.

$\begin{array}{lll} & \text { Opettaja: } & \text { MITÄS täällä piti lukea? } \\ 123 & \text { Teacher: } & \text { WHAT were you supposed to read? } \\ & & \text { Nyt kuulen ääntä käytävälle asti. } \\ & & \text { Now I heard such loud noise even to the corridor. } \\ 125 & & (0.4) \\ 126 & & \text { No [mut Osku- } \\ & \text { Viljo: } & \text { Yes [but Osku- } \\ 127 & \begin{array}{l}\text { Viljo: } \\ \text { Opettaja: }\end{array} \\ 128 & \begin{array}{l}\text { Teacher: } \\ \text { Viljo: }\end{array} & \text { \#Osku nauroi kun mä liukastuin.\# } \\ 129 & \text { Viljo: } & \text { \#Osku was laughing when I slipped over. \# } \\ & \text { Opettaja: } & \text { Olikos se Osku kivasti tehty? } \\ 130 & \text { Teacher: } & \text { Was that done nicely, Osku? }\end{array}$




$\begin{array}{llll} & \text { Osku: } & \text { Nooh (0.4) ei:. } \\ 131 & \text { Osku: } & \text { Ohh, (0.4) no:. } \\ & \text { Opettaja: } & \text { No ei. Mitä sinä nyt voisit sanoa? } \\ 132 & \text { Teacher: } & \text { Well no. What you could say now? } \\ 133 & & (2.0) \\ & \text { Osku: } & \text { No: anteeks. } \\ 134 & \text { Osku: } & \text { O:h, sorry. } \\ & \text { Opettaja: } & \text { Ymmhh. (.). Jos jollekin sattuu haaveri, nin jo se itsessään tuntuu hyvin } \\ 135 & \text { Teacher: } & \text { Ymmhh. (.) If someone encounters a mishap it itself feels very bad.(.) And it } \\ & & \text { pahalta. Ja se tuntuu vielä pahemmalta jos joku sille nauraa. } \\ 136 & & \text { feels even worse, if someone laughs at that. }\end{array}$

The teacher settles the dispute according to the classroom order. She makes the formal moral order of classroom visible by accounting for the noise (line 123). To her, the noise is the salient thing and this is what she orients to at first: Now / heard such loud noise even to the corridor (line 125). The teacher does not address the next speaker, but Viljo responds. In this way Viljo settles in teacher's frame and accepts responsibility for causing noise. He starts with yes, but then uses the polarity marker but: Yes but Osku- (line 127). He gives a justifying account, an account in which his breach of the moral order is morally justified (Scott \& Lyman 1968) on line 129: Osku was laughing when I slipped over. In his account he posits Osku to be the morally responsible one and that the pejorative quality of conduct is associated with Osku. Viljo's tone of voice indicates that he has hurt his feelings.

The teacher accepts Viljo's account and immediately, do not call account from Osku, instead rebukes him: Was that done nicely, Osku? (line 130). Osku starts all his turn with the particle well or oohh (line 131), which can indicate that he has to agree with the teacher. This marker ohh downplays his own agency. Also when Osku apologizes, he starts his turn again with oh: O:h, sorry (line 134). It seems that the resolution is not mutually acceptable by both boys, and that the dispute is solved only in teacher's frame (see Danby \& Baker 1998b).

Viljo did not seek support from Tatu when it was offered. But when the teacher intervenes, Viljo choices account in which is usually expected that teacher will align: laughing at a mishap which has 
hurt feelings. Viljo do not tell anything about his contribution to the dispute. This shows that children are competent to act in different frames and moral orders in classroom and apply the frames and moral orders to their own agendas.

\section{Discussion and conclusions}

The present research highlights four points with respect to children's disputes and threats. First, this study showed how pretend threats work differentially to other sort of threats. Compared to Church's \& Hester's (2012) and Hepburn's \& Potter's (2011) work, the threats in pretence did not bring a closure to the dispute, instead they escalated the dispute. The dispute was ongoing as long as the teacher arrived. The boys utilized different kinds of threats: unspecified outcome threats, withhold-threats (friendship), harmful threats, but no telling on-threats (see pages 4-5). As discussed in the beginning of this paper, it has previously been shown how the idea of threat is performative, like bringing the closure to the dispute (Church 2009; Church \& Hester 2012). The role of a threat is to make something happen, thus the threat-maker's intention must conform to the conditions for a threat and be perceived as an intended threat by the hearer.

In this study, the pretend threats were preceded by threats and thus were more like expressions of intentions and insufficient to bring the closure to the dispute. That is because threats were posited in the pretend frames and the boys were unable to accomplish them 'here and now', and the threats became empty in that sense. In addition, in a video game frame, the frame itself is a game and part of the game purpose is to continue it. In games, opposition is expected Thus, the use of pretend threats serves a different purpose to other sorts of threats. Even though they work differentially, they are commonly used resources in children's disputes. Also the basic structure of pretend threats was different; the two-part structure including if and then-clause was missing. 
The analysis showed however, that the threats were not only light intentions, but they were escalated. For example Viljo's threat was each time bigger, at first he escalated his threat in video game frame three times and then in real life: from sending viruses, to sending badass viruses, then withholding from the co-operation in game playing and finally withholding from the friendship. In fight pretence he at first threatened with kicking and then kicking Osku into the 'universe'.

Second, from the detailed analysis of talk it became possible to examine how the boys invoked and shifted across different frames. The boys were sitting in their desks, and the dispute never escalated from verbal to physical. Pretence turned out to be a significant resource in the dispute when the boys did not move seats or do anything physically. Compared to the other research concerning children's use of pretence, in this study pretence was invoked during the dispute. It was used spontaneously, as well as the shift to some other frame. The shifts are not analogical with stepwise movement described by Jefferson 1984, in which topic movement occurs from topic to topic. Pretence is not always built collectively, but in this study the pretence was shared: both boys had interest and knowledge to use the same pretend frames. They both always shared the knowledge of the play and fight context. The boys' background knowledge of each other and experience with video games provided them resources. They understand what each other means through shared frames.

Third, the boys were disputing in a classroom lesson of mother tongue and literacy, but their threats were based on out-of-school activities. These threats indicate that video game activity can be 'done' in the classroom. However, although the video games can't be played in the classroom, some of the elements of the game can be played out. Although the boys did not have the chance to play the games they took the violent and fighting aspects of video games as a resource in this dispute. It is not the intention of this article to show why the boys did this, but rather to suggest that this was an option available to them as part of a game frame, whereas it is not an expected behaviour option in real life. However, after fighting in the video game frame, the boys started to build attack strategies in a fight which was in the pretend frame, but with 'real' people. It seems that what happens in the video game world impacts the real world. Thus, video games have real life consequences. 
Fourth, there was an ongoing arrival of other children to the classroom and the teacher was the last to enter. However, the other children sat and read their books almost without paying any attention to the dispute which was occurring as a cross conversation through the classroom because Osku and Viljo were sitting on different sides of the classroom. The only time when a third person, Tatu, intervened was when Osku was calling Viljo a lousy friend. Tatu came to the classroom at the same time as Osku and Viljo, and presumably he had heard the whole dispute, but the only time when he attended was when the dispute was happening in real life frame and focused on the other person himself. This shows that there are different moral orders in real and pretend frames and when the insults occurs in the real life frame it does disrupt the established moral order. It might be that because in video frames consequences are not as stable, real or in the personal level, the moral order is also different. It also shows that children are very sensitive to the real and pretend and knowing the frame of intended action is important.

The applicability of framing allows seeing different and overlapping realities in children's peer interaction. It also allows adults understand children's social worlds in relation to engagement with new technologies. By invoking different frames it was possible for the boys to elevate their status in different frames and with the use of threats. The line between real and pretend is very slippery, and the harmful threats including violence were invoked in both frames. Video reality effects to real and opposite, and the interplay is ongoing through children's social competencies. However, moral order was different in pretend and real life frames. That is why pretend threats might be valid resources in a friend dispute.

Investigating threats in pretend frames offers new ways to both understand the phenomenon of threats more deeply as well as propose alternate strategies for teachers to deal with the issue. It is obvious, that disputes should not hinder the formal school work and they have to be settled. However, adult intervention may not necessarily be appropriate in relation to children's peer cultures, and in the light of this analysis the teacher's resolution seem simplistic. Teachers' commonly shared practice to posit only one party in charge of the dispute neglects that disputing is always an interactional 
achievement, not only an achievement of an individual person. That is why seeking only one guilty party of the dispute may not be the best way to solve the conflict. It is important to note that labelling a child as antisocial is insufficient. The risk is that the condemned child becomes misunderstood.

\section{REFERENCES}

Aarsand, Pål, 2008. Frame switches and identity performances: Alternating between online and offline. Text \& Talk 28-2, 147-165.

Aarsand, Pål, \& Aronsson, Karin, 2009/forthcoming. Response cries and other gaming moves. Toward an intersubjectivity of gaming. Journal of Pragmatics.

Antaki, Charles, 1994. Explaining and arguing. London: Sage.

Bateman, Amanda, 2010. Children's co-construction of context; prosocial and antisocial revisited. University of Wales Svansea. PhD thesis.

Bateman, Amanda, 2011. Huts and heartache: The affordance of playground huts for legal debate in early childhood social organization. Journal of Pragmatics 43, 3111-3121.

Bateman, Amanda, 2012. Forging friendships: The use of collective pro-terms by pre-school children. Discourse Studies 14, 165-180.

Benoit, Pamela, 1983. The Use of Threats in Children's Discourse. Language and Speech 4, 305-329.

Bergmann, Jörg, 1998. Introduction: Morality in discourse. Research on Language and Social Interaction 31, 279-294.

Björk-Willén, Polly, 2012. Being doggy: Disputes embedded in preschoolers' family role-play. In:

Danby, S. \& Theobald, M. (Eds.), Disputes in Everyday Life: Social and Moral Orders of Children and Young People. Bingley: Emerald, 119-140.

Butler, Carly, 2008. Talk and Social Interaction in the Playground. Hampshire: Ashgate.

Church, Amelia, 2009. Preference organisation and peer disputes: How young children resolve conflict. Aldershot: Ashgate. 
Church, Amelia \& Hester, Sally, 2012. Conditional threats in young children's peer interaction. In Danby, S. \& Theobald, M. (Eds.), Disputes in Everyday Life: Social and Moral Orders of Children and Young People. Bingley: Emerald, 243-265.

Cromdal, Jakob, 2004. Building bilingual oppositions: Code switching in children's disputes. Language in Society, 33, 33-58.

Cobb-Moore, Charlotte, Danby, Susan \& Farrell, Ann, 2008. Young children as rule makers. Journal of Pragmatics 41, 1477 - 1492.

Corsaro, William, 1985. Friendship and peer culture in the early years. Norwood, New Jersey: Ablex Publishing.

Danby, Susan \& Baker, Carol,1998a. How to be masculine in the block area. Childhood, 5, 151-175.

Danby, Susan \& Baker, Carol, 1998b. What's the problem? Restoring social order in the preschool classroom. In Hutchby I. \& Moran-Ellis J. (Eds.), Children and the social competence Arenas of action. Amsterdam: Jonn Benjamins, 99-140.

Danby, Susan \& Baker, Carol, 2000. Unraveling the fabric of social order in block area. In Hester, S. and Francis, D. (Eds.) Local educational order: Ethnomethodological studies of knowledge in action. Amsterdam: John Benjamins.

Danby, Susan \& Theobald, Maryanne, (Eds.) 2012. Disputes in Everyday Life: Social and Moral Orders of Children and Young People. Bingley: Emerald.

Davidson, Christina, 2012. When "Yes" turns to "No". Young children's disputes during computer game playing in the home. In Danby, S. \& Theobald, M. (Eds.), Disputes in Everyday Life: Social and Moral Orders of Children and Young People. Bingley: Emerald, 335-276.

Garfinkel, Harold, 1967. Studies in ethnomethodology. Englewood cliffs, New Jersey: Prentice-Hall.

Goffman, Erwing, 1959. The presentation of self in everyday life. Garden city, New York: Double Day.

Goffman, Erwing, 1974. Frame Analysis: An Essay on the Organization of Experience. Cambridge: Harvard University Press.

Goldman, lan, 1998. Child's Play: Myth, Mimesis and Make-believe. Oxford: Berg. 
Goodwin, Charles, 2012. The co-operative, transformative organization of human action and knowledge. Journal of Pragmatics 46, 8-23.

Goodwin, Marjorie Harness, 1982. Process of dispute management among urban black children. American Ethnologist 9, 76-96.

Goodwin, Marjorie Harness, 1990. He said - she said: Talk as social organization among black children. Bloomington: Indiana University Press.

Goodwin, M. 2007. Participation and embodied action in preadolescent girls' assessment activity. Research on Language and Social Interaction 40, 353-375.

Goodwin, Marjorie Harness \& Goodwin, Charles 1987. Children's arguing. In S. U. Philips \& S. Steele \& C. Tanz (Eds.), Language, gender and sex in comparative perspective. Cambridge: Cambridge University Press, 200-248.

Goodwin, Marjorie Harness, Goodwin, Charles \& Yaeger-Dror, Malchar, 2002. Multi-modality in girls' game disputes. Journal of Pragmatics, 34, 1621-1649.

Grieshaber, Susan \& McArdle, Felicity, 2010. The Trouble with Play. Maidenhead : Open University Press.

Hay, D. F., \& Ross, H. S. 1982. The Social Nature of Early Conflict. Child Development, 53, 105-113.

Hepburn, Alexa \& Potter Jonathan, 2011. Threats: Power, family mealtimes, and social influence.

British Journal of Social Psychology 50, 99-120.

Heritage, John, 1978. Aspects of the flexibilities of natural language use. Sociology $12,79-103$.

Heritage, John, 2001. Goffman, Garfinkel and conversation analysis. In: Wetherall, M., Taylor, S. J. \& Yates, S. (Eds.) Discourse Theory and Practice: A Reader for Researchers. London: Sage, 47-56.

Hutchby, lan and Woofit, Robin 2008. Conversation Analysis: Principles, Practices and Applications. $2^{\text {nd }}$ Edition. Cambridge: Blackwell Publishers.

Jefferson, Gail, 1984. On stepwise transition from talk about a trouble to inappropriately nextpositioned matters. In: Atkinson, J. M. \& Heritage, J. (Eds.) Structures of Social Action: Studies in Conversation Analysis. Cambridge: Cambridge University Press: 191-222

Linderoth, Jonas, 2012. The Effort of Being in a Fictional World: Upkeyings and Laminated Frames in MMORPGs. Symbolic Interaction, 35, 474-492. 
MacLachlan, Gale \& Reid, Ian, 1994. Framing and Interpretation. Carlton Victoria: Melbourne University Press.

Mashford-Scott, Angela \& Church, Amelia, 2011. Promoting Children's Agency in Early Childhood Education. Novitas-Royal (Research on Youth and Language) 5, 15-38.

Maynard, Douglas, 1985. On the functions of social conflict among children. American Sociological Review 50, 207-223.

Nikander Pirjo, 2008. Working with transcripts and translated data. Qualitative Research in Psychology 5, 225-231.

Pomerantz, Anita, 1984. Agreeing and Disagreeing with Assessments: Some Features of Preferred/Dispreferred Turn Shapes in Atkinson, J. M. and Heritage, J. (Eds.) Structures of Social Action: Studies in Conversation Analysis. Cambridge: Cambridge University Press, 57-101.

Psathas, George, 1995. Conversation analysis: The study of talk-in-interaction. California: Sage.

Sacks, Harvey, 1987. On the preferences for agreement and contiguity in sequences in conversation. In Button G. and Lee J. R. E. (Eds.), Talk and social organization. Clevedon: Multilingual Matters.

Sacks, Harvey, 1995. Lectures on Conversation. Oxford: Basil Blackwell.

Sawyer, Keith, 1997. Pretend Play as Improvisation: Conversation in the Preschool classroom. New Jersey: Lawrence Erlbaum Associates, Inc.

Schegloff, Emanuel, A. 2007. Sequence organization in interaction. Cambridge : Cambridge University Press.

Scott, Marvin, B. \& Lyman, Stanford, M. 1968. Accounts. American Sociological Review 33, 46-62.

Sheldon, Amy, 1996. You can be the baby brother, but you aren't born yet: Preschool girls' negotiation for power and access in pretend play. Research on Language and Social Interaction 29, $57-80$.

Sidnell, Jack, 2010. Conversation Analysis: An introduction. Oxford, Wiley-Blackwell Publishing. Sidnell, Jack, 2011. The epistemics of make-believe. In Stivers, T., Mondada. L. \& Steensig, J. (Eds.) The Morality of Knowledge in Conversation. Cambridge : Cambridge University Press, 131-158. 
Streeck, Jürgen, 1986. Social order in child communication : a study in microethnography. Ny: John Benjamins.

Sjöblom, Björn \& Aronsson, Karin, 2012. Facing Death in Computer Gaming. In Danby, S. \&

Theobald, M. (Eds.), Disputes in Everyday Life: Social and Moral Orders of Children and Young People. Bingley: Emerald, 377-405.

Ten Have, Paul, 2007. Doing conversation analysis. A Practical guide. Sage: London.

Theobald, Maryanne, 2013. Ideas as "possessitives": Claims and counter claims in a playground dispute. Journal of Pragmatics 45, 1-12.

Walkerdine, Valerie, 2007. Children, gender, virtual games: Towards a relational approach to multimedia. London: Palgrave Macmillan. 
APPENDIX 1: Transcript system

The system used to transcribe the interactional data was based on the system developed by Gail Jefferson and described in Psathas (1995). The following features were used in the transcript.

((says)) transcribers description of the talk-in-interaction

(.) pause timed in micro-tenths of a second

$\uparrow$ That's rising intonation

$\downarrow$ have falling intonation

pause timed in seconds

$((--)) \quad$ something inaudible

you emphasis

NO greater emphasis

tha- interrupted word

$=\quad$ latching between utterances

${ }^{\circ} \mathrm{you}^{\circ} \quad$ talk has a noticeably lower volume than surrounding talk

.h audible in-breath

h. audible out-breath

[ ] overlap

\# creak

$>$ faster $\quad$ speech is faster than surrounding speech

\$ smile talk

\& $\quad$ sing

no: $\quad$ sound extended 